\title{
Isotope Exchange in Disulfur Monoxide-Water Charged Complexes: A Mass Spectrometric and Computational Study
}

\author{
Giulia de Petris, ${ }^{\text {a }}$ Anna Troiani, ${ }^{\text {a }}$ Giancarlo Angelini, ${ }^{\text {b }}$ Ornella Ursini, ${ }^{\text {b }}$ \\ Andrea Bottoni, ${ }^{\mathrm{C}}$ and Matteo Calvaresi ${ }^{\mathrm{c}}$

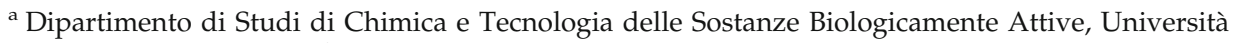 \\ "La Sapienza," Rome, Italy \\ b Istituto di Metodologie Chimiche, Area della Ricerca di Roma del CNR, Monterotondo Stazione, Rome, Italy \\ c Dipartimento di Chimica "G. Ciamician," Università degli Studi di Bologna, Bologna, Italy
}

A hitherto unknown, isotope-exchange reaction is studied in ionized gaseous mixtures containing disulfur monoxide and water. The kinetics, mechanism, and intermediate of the reaction are investigated by experimental and theoretical methods. The reactivity of the $\mathrm{S}_{2} \mathrm{O}^{\cdot+}$ cation with water is investigated under a wide range of pressures ranging from $10^{-7}$ to $10^{-4}$ Torr, by FT-ICR, TQ, and high-resolution CAD mass spectrometry. In the high-pressure limit the reaction proves to be a route to strongly bound sulfur-containing species. (J Am Soc Mass Spectrom 2007, 18, 1664-1671) (C) 2007 American Society for Mass Spectrometry

$\mathrm{T}$ The reactivity of the $\mathrm{S}_{2} \mathrm{O}^{++}$ion is almost unknown compared to the valence-shell isoelectronic $\mathrm{O}_{3}^{++}$ and $\mathrm{SO}_{2}^{+}$ions. The scant information available adds to the difficulty to prepare $\mathrm{S}_{2} \mathrm{O}^{++}$by ionization of $\mathrm{S}_{2} \mathrm{O}$, which is very unstable and not easily synthesizable with high purity [1]. Despite being unstable, $\mathrm{S}_{2} \mathrm{O}$ can be trapped in transition-metal complexes because of its $\pi$-acceptor ability [2]. This interaction has also been theoretically investigated in charged complexes, such as $\left[\mathrm{MnS}_{2} \mathrm{O}\right]^{+}[3]$. Thus far the only experimentally observed charged complex is [OCS $\left.-\mathrm{S}_{2} \mathrm{O}\right]^{++}$and, to our knowledge, the only investigated reaction of $\mathrm{S}_{2} \mathrm{O}^{++}$is the sulfur-atom transfer from SCO $[4,5]$.

The knowledge of the reactions of $\mathrm{S}_{2} \mathrm{O}$ and its cation $\mathrm{S}_{2} \mathrm{O}^{+}$is important because disulfur monoxide is an atmospherically relevant species. It has been suggested that $\mathrm{S}_{2} \mathrm{O}$ is among the sulfur compounds that color the surface of Io and give similar spectral features to Europa [6, 7]. Europa contains more water than Earth, and data from the Galileo mission suggest the possible existence of a water ocean beneath the surface [8]. Moreover, magnetospheric ions and electrons from the Io plasma torus sputter the water-ice surface producing neutral and ionic products in Europa's tenuous atmosphere $[9,10]$.

In this work we have studied by mass spectrometric techniques and computational methods the reaction between the $\mathrm{S}_{2} \mathrm{O}^{+}$ion and the water molecule, as a simple model for the reactivity of $\mathrm{S}_{2} \mathrm{O}^{\cdot+}$. The $\left[\mathrm{S}_{2} \mathrm{O}-\mathrm{H}_{2} \mathrm{O}\right]^{\cdot+}$ complex was studied by high-resolution

Address reprint requests to Prof. Giulia de Petris, Università "La Sapienza," Dipartimento di Studi di Chimica e Tecnologia delle Sostanze Biologicamente Attive, Piazzale Aldo Moro 5, 00185 Rome, Italy. E-mail: giulia. depetris@uniroma1.it collisionally activated dissociation (CAD) mass spectrometry, which allowed the necessary separation of isobaric species containing different combinations of oxygen and sulfur atoms. The study, performed in the wide pressure range $10^{-7}-10^{-4}$ Torr, demonstrates the occurrence of isotope exchange in all the investigated regimes and indicates, in the high-pressure limit, a route to strongly bound sulfur-containing species [11].

\section{Materials and Methods}

\section{FT-ICR (Fourier Transform-Ion Cyclotron Resonance) Experiments}

The experiments were performed by use of an EXTREL FTMS 2001 mass spectrometer, equipped with modified electronic and operative systems by IonSpec/Varian Inc. (Palo Alto, CA, USA), and with a MKS ion gauge controller type 290. $\mathrm{S}_{2} \mathrm{O}$ was prepared in situ in a glassy reactor by reaction of thionyl chloride $\mathrm{SOCl}_{2}$ and a mixture of $\mathrm{HgS}$ and $\mathrm{Ag}_{2} \mathrm{~S}(1: 1 \mathrm{wt} / \mathrm{wt})$, previously dried for 2 days at $393 \mathrm{~K}$. The solid mixture was heated to $443 \mathrm{~K}$, whereas the bulb containing $\mathrm{SOCl}_{2}$ was cooled by liquid nitrogen to obtain slow evaporation. The glassy reactor was connected to a glassy trap containing 4 - $\AA$ molecular sieves kept at $253 \mathrm{~K}$. To minimize the $\mathrm{S}_{2} \mathrm{O}$ and $\mathrm{H}_{2} \mathrm{O}$ concentrations in the ICR cell, the foreline valve was opened during the experiment. The gaseous mixture, essentially formed by $\mathrm{SO}_{2}, \mathrm{~S}_{2} \mathrm{O}$, and minor amounts of $\mathrm{H}_{2} \mathrm{O}$, was admitted into the ICR cell at the pressure of about $1.4 \times 10^{-7}$ Torr. $\mathrm{H}_{2}{ }^{18} \mathrm{O}$ was introduced at pressures ranging from 1.7 to $8.5 \times 10^{-7}$ Torr.

The pressure calibration was carried out at different pressures $\left(3 \times 10^{-8}\right.$ and $3 \times 10^{-7}$ Torr $)$, using the rate 
constant values for the reference reactions $\mathrm{CH}_{4}^{+}+$ $\mathrm{CH}_{4} \rightarrow \mathrm{CH}_{5}^{+}+\mathrm{CH}_{3}\left(k=1.1 \times 10^{-9} \mathrm{~cm}^{3} \mathrm{~s}^{-1} \mathrm{molec}^{-1}\right)$ and $\mathrm{C}_{2} \mathrm{H}_{3}^{+}+\mathrm{CH}_{4} \rightarrow \mathrm{C}_{3} \mathrm{H}_{5}^{+}+\mathrm{H}_{2}\left(k=1.9 \times 10^{-10} \mathrm{~cm}^{3} \mathrm{~s}^{-1}\right.$ molec $^{-1}$ ) [12]. The obtained value, corrected for the response factor of $\mathrm{H}_{2} \mathrm{O}$, is much the same as that obtained by standard procedures based on the correlation between relative sensitivity and polarizability of the gas $[13,14]$.

The $\mathrm{S}_{2} \mathrm{O}^{+}$ions were generated by $22 \mathrm{eV}$ ionization and, after a "cooling" time of $0.5 \mathrm{~s}$, they were isolated using an "arbitrary wave-form" isolation procedure. The pseudo-first-order rate constant $k_{1}\left(\mathrm{~s}^{-1}\right)$ was obtained from the slope of the logarithmic plot of the relative ion intensity versus the reaction time (typically $\left.\mathrm{R}^{2}=0.998\right)$. The bimolecular rate constant $k\left(\mathrm{~cm}^{3} \mathrm{~s}^{-1}\right.$ molecule ${ }^{-1}$ ) was obtained by $k_{1} /\left[\mathrm{H}_{2}{ }^{18} \mathrm{O}\right]$. The rate constants are vulnerable to a number of uncertainties that arise for the most part from the measurement of the neutral pressure, and the uncertainty attached to the $k$ value is evaluated $\pm 30 \%$. In equilibrium experiments, $k_{1}$ and $k_{-1}$ for a reversible pseudo-first-order reaction were obtained by the best fitting of the ionic concentrations with the equation $\mathrm{c}=\mathrm{c}_{\mathrm{eq}}+\left(\mathrm{c}_{\mathrm{o}}-\mathrm{c}_{\mathrm{eq}}\right) \mathrm{e}^{\text {kovt }}$ (typically $\left.\mathrm{R}^{2}=0.995\right)$, where $k_{o v}=k_{1}+k_{-1}$ and $k_{1}=$ $k_{o v}\left(\mathrm{c}_{\mathrm{o}}-\mathrm{c}_{\mathrm{eq}}\right) / \mathrm{c}_{\mathrm{o}}$. The measured $\left[\mathrm{H}_{2}{ }^{18} \mathrm{O}\right] /\left[\mathrm{H}_{2} \mathrm{O}\right]$ ratio satisfactorily equals the ratio between the obtained $k_{1}$ and $k_{-1}$ values, with the maximum deviation of $\pm 20 \%$. The reaction efficiency, expressed as the ratio of the bimolecular rate constant $k$ to the collision rate constant, was calculated according to the ADO theory or by the $\mathrm{Su}$ and Chesnavich parametrized variational theory, which gave closely similar results [15].

\section{CI-CAD (Chemical Ionization-Collisionally Activated Dissociation) Experiments}

The experiments were performed using a modified ZABSpec oa-TOF instrument (Waters/VG Micromass, Hertfordshire, UK) of EBE-TOF configuration, where E and $\mathrm{B}$ stand for electric and magnetic sectors, respectively, and TOF stands for orthogonal time-of-flight mass spectrometer [16]. The instrument was fitted with an EI/CI (electron ionization/chemical ionization) source, a gas cell located in the first field-free region, and two pairs of cells located after the magnet in the second field-free region and in the TOF sector, respectively. Typical operating conditions were as follows: accelerating voltage, $8 \mathrm{keV}$; source temperature, $433 \mathrm{~K}$; repeller voltage, $0 \mathrm{~V}$; emission current, $1 \mathrm{~mA}$; nominal electron energy, $50 \mathrm{eV}$; and source pressure ranging from 0.1 to 0.2 Torr as read inside the source block by a Magnehelic differential pressure gauge. Highresolution CI mass spectra were recorded at 15,000 full width at half-maximum (fwhm) at the first detector. The CAD/TOF spectra were recorded at $0.8 \mathrm{keV}$ in the TOF sector of the instrument, after mass and energy selection of the ion. Helium was used as the target gas; it was admitted into the collision cell at such a pressure to achieve $80 \%$ transmittance.
The chemicals were research-grade products with the following stated purity: elemental sulfur-S (Aldrich, $99.998 \mathrm{~mol} \%$ ), elemental sulfur- ${ }^{34} \mathrm{~S}$ (Aldrich, $99.5 \%{ }^{34} \mathrm{~S}$ atoms), $\mathrm{H}_{2}{ }^{18} \mathrm{O}$ (Isotec, $97 \%{ }^{18} \mathrm{O}$ atoms), ${ }^{18} \mathrm{O}_{2}$ (CIL, 95\% ${ }^{18} \mathrm{O}$ atoms). Elemental sulfur was introduced through a direct insertion probe and heated in vacuo at temperatures not exceeding $400 \mathrm{~K} . \mathrm{S}_{2} \mathrm{O}$ was prepared in situ by reaction of thionyl chloride $\mathrm{SOCl}_{2}$ and silver sulfide $\mathrm{Ag}_{2} \mathrm{~S}$ heated in a Pyrex tube to $423 \mathrm{~K}$.

\section{TQMS (Tandem Quadrupole Mass Spectrometry) Experiments}

The experiments were performed using a Waters Quattro Micro Tandem GC-MS/MS equipped with a cool chemical ionization source. The reactant ions were mass-selected by the first quadrupole (Q1) and driven to the second quadrupole (Q2), an RF-only hexapole, containing the neutral gas at pressures ranging from $8 \times 10^{-5}$ to $1 \times 10^{-3}$ Torr. The ion-molecule reactions were investigated at nominal collision energies of $0 \mathrm{eV}$ and the charged products were analyzed by the third quadrupole (Q3).

\section{Computational Methods}

All the computations were performed with the Gaussian 03 series of programs [17]. The geometry of the various critical points on the doublet reaction surface was fully optimized with the gradient method available in the Gaussian package at the density functional theory (DFT) level using the nonlocal hybrid Becke's threeparameter exchange functional denoted as B3LYP [18] and the aug-cc-pVTZ basis set [19]. A computation of the harmonic vibrational frequencies was carried out to determine the nature of each critical point. Single-point computations at the CCSD(T) level (aug-cc-pVTZ basis) were carried out on the DFT-optimized structures to obtain more accurate energy values. The energy values include thermal corrections at $298 \mathrm{~K}$ computed at the DFT level.

\section{Results and Discussion}

\section{The O-Exchange Reaction}

Under FT-ICR conditions, $\mathrm{S}_{2} \mathrm{O}^{++}(\mathrm{m} / \mathrm{z} 80)$ is apparently unreactive with $\mathrm{H}_{2} \mathrm{O}$, whereas its reaction with $\mathrm{H}_{2}{ }^{18} \mathrm{O}$ yields the $\mathrm{S}_{2}{ }^{18} \mathrm{O}^{-+}$ion $(\mathrm{m} / \mathrm{z}$ 82) from the following isotope exchange reaction:

$$
\mathrm{S}_{2} \mathrm{O}^{++}+\mathrm{H}_{2}{ }^{18} \mathrm{O} \rightleftarrows \mathrm{S}_{2}^{18} \mathrm{O}^{+}+\mathrm{H}_{2} \mathrm{O}
$$

In the absence of $\mathrm{H}_{2} \mathrm{O}$, reaction (1) can reasonably be treated as an irreversible process obeying pseudo-firstorder decay kinetics. To minimize the effect of the amounts of $\mathrm{H}_{2} \mathrm{O}$ invariably introduced with $\mathrm{S}_{2} \mathrm{O}$, the 
reaction was performed at $\left[\mathrm{H}_{2}{ }^{18} \mathrm{O}\right] /\left[\mathrm{H}_{2} \mathrm{O}\right]$ ratios as high as $30-40$. Under these conditions, the $\mathrm{S}_{2}{ }^{18} \mathrm{O}^{-+}$product was isolated to verify the occurrence of the back reaction. The failure to observe any $\mathrm{S}_{2} \mathrm{O}^{++}$product first indicates that the available amount of water is not sufficient for a detectable back reaction to occur. Second, it shows that, compared to the O-exchange, the charge exchange between $\mathrm{S}_{2}{ }^{18} \mathrm{O}^{++}$and $\mathrm{S}_{2} \mathrm{O}$ is ineffective at the used concentrations of $\mathrm{S}_{2} \mathrm{O}$. Under these conditions the measured rate constant was $k=9.2 \times 10^{-11} \pm$ $30 \% \mathrm{~cm}^{3} \mathrm{~s}^{-1}$ molecule $^{-1}$.

A nearly identical value was obtained from rate constant calculations for a reversible pseudo-first-order reaction. Figure 1 reports a typical equilibrium experiment performed utilizing a $1 / 1 \mathrm{H}_{2} \mathrm{O} / \mathrm{H}_{2}{ }^{18} \mathrm{O}$ mixture. After introduction of $\mathrm{S}_{2} \mathrm{O}$, the $\mathrm{m} / \mathrm{z} 18 / 20$ ratio became $1.1 / 1$ as a result of the amount of $\mathrm{H}_{2} \mathrm{O}$ added by the synthesis mixture. The same 1.1/1 ratio was found between $\mathrm{S}_{2} \mathrm{O}^{+}$and $\mathrm{S}_{2}{ }^{18} \mathrm{O}^{++}$when the equilibrium is reached. This finding further confirms that the charge exchange between $\mathrm{S}_{2}{ }^{18} \mathrm{O}^{+}$and $\mathrm{S}_{2} \mathrm{O}$ does not affect the result under the used experimental conditions. The experiments were performed at different $\mathrm{H}_{2} \mathrm{O} / \mathrm{H}_{2}{ }^{18} \mathrm{O}$ ratios ranging from 0.4 to 1.5 , and the measured rate constant was $k=9.4 \times 10^{-11} \pm 30 \% \mathrm{~cm}^{3} \mathrm{~s}^{-1}$ molecule $^{-1}$, corresponding to a reaction efficiency $k / k_{\text {coll }}$ of 0.05 .

The O-exchange was found to be effective even under higher-pressure regimes, in the high-pressure source of a multisector mass spectrometer as well as in the cell of a tandem TQ mass spectrometer. Comparable amounts of $\mathrm{S}_{2}{ }^{18} \mathrm{O}^{++}$and $\mathrm{S}_{2} \mathrm{O}^{++}$were invariably observed from the reactions of either $\mathrm{S}_{2} \mathrm{O}^{++}$with $\mathrm{H}_{2}{ }^{18} \mathrm{O}$ or $\mathrm{S}_{2}{ }^{18} \mathrm{O}^{+}$ with $\mathrm{H}_{2} \mathrm{O}$.

\section{The $\left[\mathrm{H}_{2}, \mathrm{~S}_{2}, \mathrm{O}_{2}\right]^{\cdot+}$ Intermediate}

The FT-ICR results suggest that reaction (1) very likely proceeds through an intermediate that however cannot

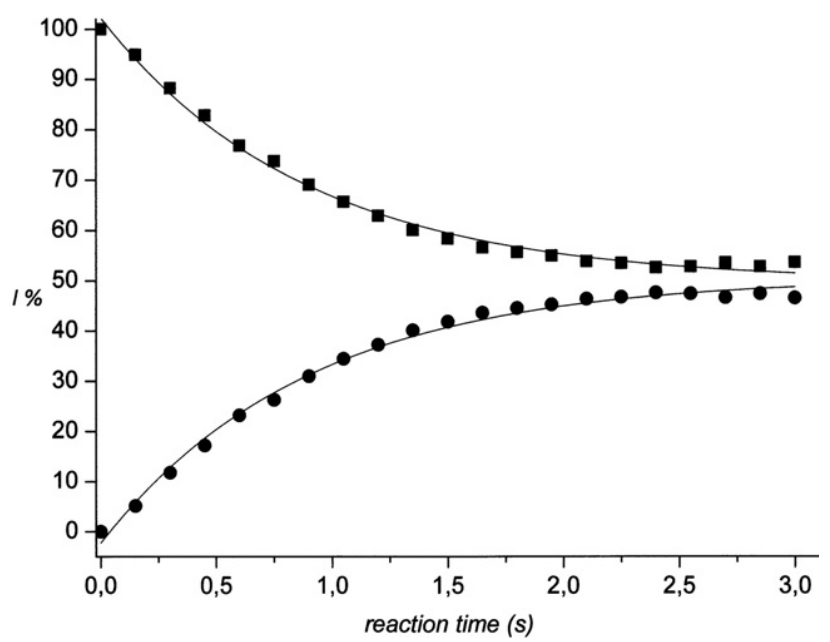

Figure 1. Time profiles and best-fit lines of the reaction of $\mathrm{S}_{2} \mathrm{O}^{++}$ with $\mathrm{H}_{2}{ }^{18} \mathrm{O}\left(\boldsymbol{\square} \mathrm{S}_{2} \mathrm{O}^{\cdot+}\right.$, $\left.\mathrm{S}_{2}{ }^{18} \mathrm{O}^{\cdot+}\right)$.

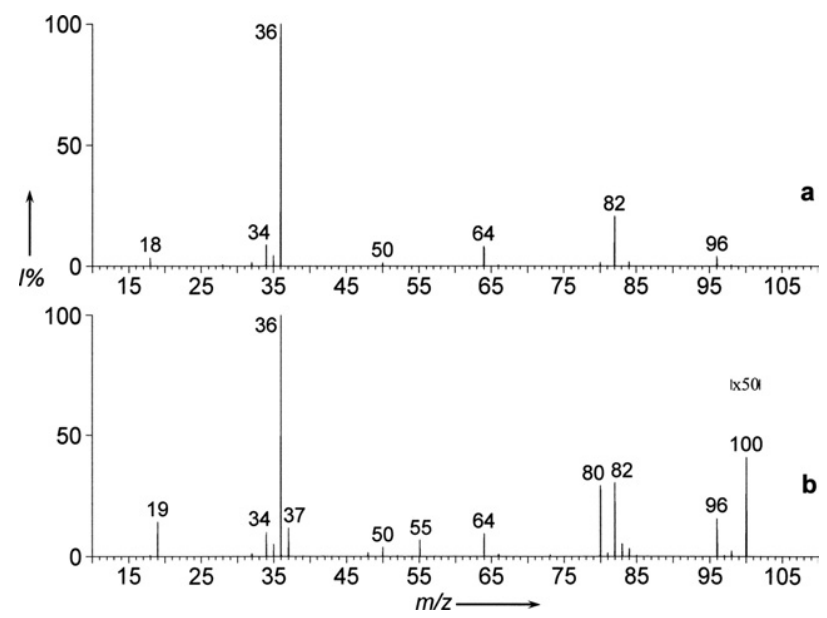

Figure 2. CI spectra of (a) $\mathrm{S} /{ }^{18} \mathrm{O}_{2}$ and (b) $\mathrm{S} /{ }^{18} \mathrm{O}_{2} / \mathrm{H}_{2} \mathrm{O}$ mixtures.

be stabilized under the low-pressure conditions typical of these experiments. On the contrary, $\left[\mathrm{H}_{2} \mathrm{~S}_{2} \mathrm{O}_{2}\right]^{+}$ions at $\mathrm{m} / \mathrm{z} 98$ were observed by high-pressure $\mathrm{CI}$ of mixtures containing $\mathrm{S}_{2} \mathrm{O}$ and $\mathrm{H}_{2} \mathrm{O}$, and from the reaction of mass selected $\mathrm{S}_{2} \mathrm{O}^{++}$ions with $\mathrm{H}_{2} \mathrm{O}$ in TQ experiments. To gain information on both the nature of the intermediate and the extent of isotopic scrambling, the structural analysis was performed by CAD mass spectrometry of labeled ions.

To this end $\left[\mathrm{H}_{2} \mathrm{~S}_{2}{ }^{18} \mathrm{OO}\right]^{++}$ions $(\mathrm{m} / \mathrm{z} 100)$ were prepared by $\mathrm{CI}$ of $\mathrm{S}_{2} \mathrm{O}$ and $\mathrm{H}_{2}{ }^{18} \mathrm{O}$ in the source of the multisector mass spectrometer. Because of the presence of ubiquitous $\mathrm{H}_{2} \mathrm{O}$ even introduced with $\mathrm{S}_{2} \mathrm{O}$, higher yields of $\mathrm{m} / \mathrm{z} 100$ ions were achieved by use of the $\mathrm{S}_{2}{ }^{18} \mathrm{O}^{-+}$reactant $(\mathrm{m} / \mathrm{z}$ 82). This can be easily obtained by $\mathrm{CI}$ of elemental sulfur $\mathrm{S}$ and ${ }^{18} \mathrm{O}_{2}$ (Figure 2a) [5]. After addition of $\mathrm{H}_{2} \mathrm{O}$, one observes the intermediate $(\mathrm{m} / \mathrm{z}$ $100)$, henceforth formally denoted as $\left[\mathrm{S}_{2}{ }^{18} \mathrm{O}-\mathrm{H}_{2} \mathrm{O}\right]^{\cdot+}$, as well as the exchanged $\mathrm{S}_{2} \mathrm{O}^{+}$ion $(\mathrm{m} / \mathrm{z}$ 80) (Figure $2 \mathrm{~b}$ ). The structural analysis of the intermediate requires high-resolution conditions to separate the isobaric ${ }^{34} \mathrm{~S}_{2} \mathrm{~S}^{+}$and $\left[{ }^{34} \mathrm{SSO}-\mathrm{H}_{2} \mathrm{O}\right]^{++}$peaks (Figure 3a). The former is the naturally occurring isotopomer of $S_{3}^{++}(\mathrm{m} / \mathrm{z}$ 96), from EI of elemental sulfur (Figure 2). The latter is the ${ }^{34} \mathrm{~S}$ isotopomer of the $\left[\mathrm{S}_{2} \mathrm{O}-\mathrm{H}_{2} \mathrm{O}\right]^{+}$ion $(\mathrm{m} / \mathrm{z}$ 98) formed by reaction of exchanged $\mathrm{S}_{2} \mathrm{O}^{-+}$ions with water (Figure $2 b$ ). Such a secondary reaction confirms the effectiveness of the O-exchange.

The CAD spectrum of the isolated $\left[\mathrm{S}_{2}{ }^{18} \mathrm{O}-\mathrm{H}_{2} \mathrm{O}\right]^{++}$ ions (Figure $3 \mathrm{~b}$ ) shows the following most important features: (1) $\mathrm{S}_{2}{ }^{18} \mathrm{O}^{++}(\mathrm{m} / \mathrm{z} 82)$ and $\mathrm{S}_{2} \mathrm{O}^{++}(\mathrm{m} / \mathrm{z} 80)$ are the most abundant fragments with identical intensity; (2) the $\mathrm{S}_{2} \mathrm{OH}^{+}(\mathrm{m} / \mathrm{z} 81)$ and $\mathrm{S}_{2}{ }^{18} \mathrm{OH}^{+}(\mathrm{m} / \mathrm{z} 83)$ ions, corresponding to protonated disulfur monoxide, also show the same abundance; (3) these fragments as well as $\mathrm{SOH}^{+}$ and $\mathrm{S}^{18} \mathrm{OH}^{+}(\mathrm{m} / \mathrm{z} 49$ and 51) denote formation of new bonds between the constituents of the $\left[\mathrm{S}_{2}{ }^{18} \mathrm{O}-\mathrm{H}_{2} \mathrm{O}\right]^{++}$ complex; and (4) the fragment at $\mathrm{m} / \mathrm{z} 33\left(\mathrm{SH}^{+}\right)$hints at species where the sulfur atom is the hydrogen bearing site. The nature of this peak was conclusively ascer- 


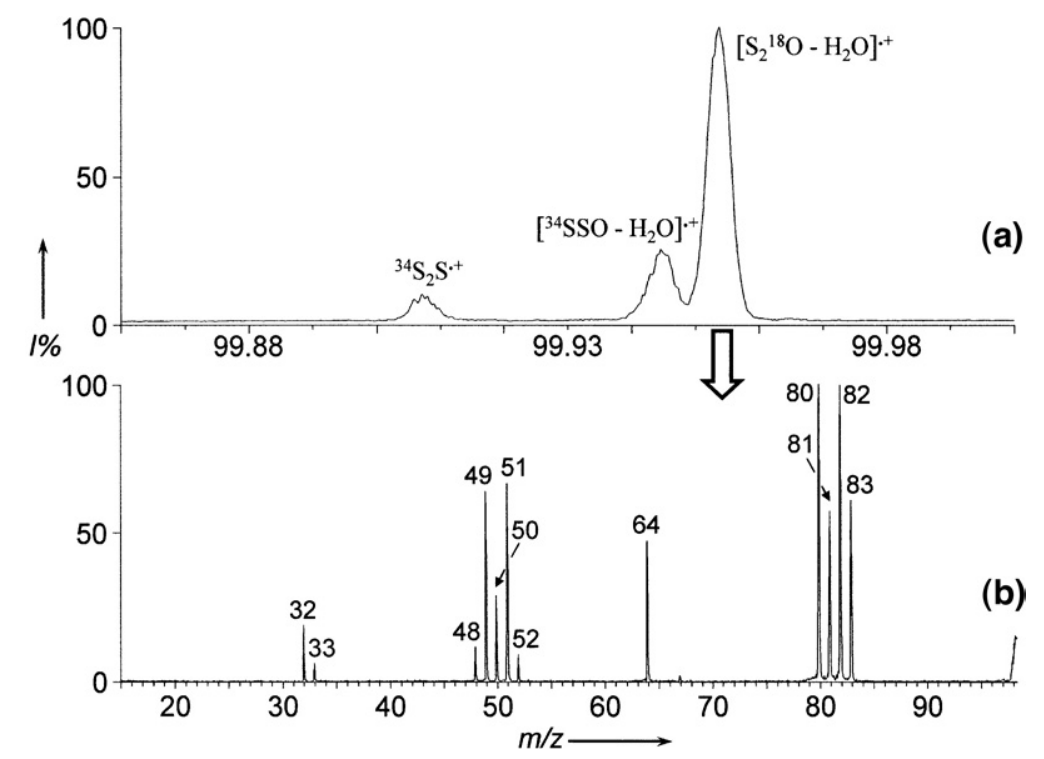

Figure 3. (a) High-resolution mass spectrum of peaks at $m / z 100$ nominal mass. (b) High-resolution $\mathrm{CAD} / \mathrm{TOF}$ spectrum of $\left[\mathrm{S}_{2}{ }^{18} \mathrm{O}-\mathrm{H}_{2} \mathrm{O}\right]^{++}$.

tained by the analysis of $\left[{ }^{34} \mathrm{~S}_{2} \mathrm{O}-\mathrm{H}_{2} \mathrm{O}\right]^{++}$ions at $m / z 102$, obtained by $\mathrm{CI}$ of elemental sulfur ${ }^{34} \mathrm{~S}, \mathrm{O}_{2}$, and $\mathrm{H}_{2} \mathrm{O}$. The CAD spectrum of the $\left[{ }^{34} \mathrm{~S}_{2} \mathrm{O}-\mathrm{H}_{2} \mathrm{O}\right]^{++}$adduct, separated from the abundant isobaric ${ }^{34} \mathrm{~S}_{3}^{+{ }^{+}}$ion, showed the $\mathrm{m} / \mathrm{z} 33$ fragment displaced to $\mathrm{m} / \mathrm{z} 35\left({ }^{34} \mathrm{SH}^{+}\right)$, which discounts the $\mathrm{O}_{2} \mathrm{H}^{+}$alternative (see Fig. $\mathrm{S} 1$ in supplemental material, which can be found in the electronic version of this article).

The analysis of the complex between $\mathrm{S}_{2}{ }^{18} \mathrm{O}^{++}$and $\mathrm{H}_{2} \mathrm{O}$ reveals that the isotope mixing is almost complete when the ionic population is presented to the structural assay. Moreover, the presence of fragments such as $\mathrm{S}_{2} \mathrm{OH}^{+}$and $\mathrm{SOH}^{+}$argues the character of a bound structure rather than a mere electrostatic $\left[\mathrm{S}_{2}{ }^{18} \mathrm{O}-\mathrm{H}_{2} \mathrm{O}\right]^{++}$complex. A very likely candidate is the $\mathrm{HOSSOH}^{+{ }^{+}}$ion, an isomer of the ionized thiosulfurous acid [20]. Such a symmetric intermediate has oxygen atoms at equivalent positions, which could account for the equal losses of labeled and unlabeled $\mathrm{OH}$ and $\mathrm{SOH}$ radicals. To elucidate these aspects, we have computationally explored the doublet potential energy surface of the $\left[\mathrm{H}_{2}, \mathrm{~S}_{2}, \mathrm{O}_{2}\right]^{++}$ system relevant to the reaction of the $\mathrm{S}_{2} \mathrm{O}^{++}$cation with a water molecule.

\section{Computational Results}

We have considered the attack of the water molecule on the two sulfur atoms $S_{1}$ and $S_{2}$ (see Scheme 1) of
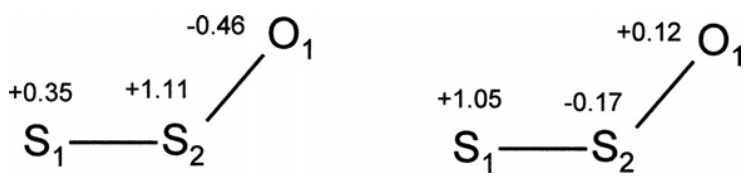

Scheme 1. Atomic charges (left) and atomic spin densities (right) computed for $\mathrm{S}_{2} \mathrm{O}^{++}$at the $\operatorname{CCSD}(\mathrm{T})$ computational level. the $\mathrm{S}_{2} \mathrm{O}^{++}$cation, and investigated all the possible species that originate from these interactions. In both cases we have observed the formation of long-range electrostatic complexes, with S1 corresponding to the attack on the terminal sulfur atom $\left(\mathrm{S}_{1}\right)$ and $\mathbf{S 2}$ corresponding to the attack on the central sulfur atom $\left(\mathrm{S}_{2}\right)$ (see Figure 4). These complexes are, respectively, 17.9 and $15.6 \mathrm{kcal} \mathrm{mol}^{-1}$ lower in energy than the asymptotic limit represented by noninteracting $\mathrm{S}_{2} \mathrm{O}^{++}$and water. A careful investigation of the potential surface has shown that S1 leads to the stable species S3, whereas no reaction paths toward new stable complexes originate from S2. This behavior can be easily rationalized if one considers the charge and spin distribution of the $\mathrm{S}_{2} \mathrm{O}^{++}$reactant ion (Scheme 1). The sulfur atoms $S_{1}$ and $S_{2}$ both carry a positive charge $(+0.35$ and +1.11 , respectively) that explains the formation of low-energy electrostatic complexes. Because the charge on $S_{2}$ is much larger than that on $S_{1}$, the distance between the water oxygen and the sulfur atom is shorter in the $\mathbf{S} 2$ complex $(2.36 \AA)$ than in the S1 complex $(2.43 \AA)$. On the other hand the spin density distribution indicates that the unpaired electron is mainly localized on $S_{1}$ (spin density +1.05 ). Thus, the formation of the new oxygen-sulfur bond (formation of S3) involves $S_{1}$ and not $S_{2}$ (spin density -0.17), consistent with the potential surface investigation.

S3 is a symmetrical species of $\mathrm{HOSSOH}$ connectivity that is located $28.5 \mathrm{kcal} \mathrm{mol}^{-1}$ below the reactants and is characterized by a syn orientation of the two $\mathrm{OH}$ groups. The formation of S3 from S1 is a concerted process that requires the completion of a new $\mathrm{O}_{2}-\mathrm{S}_{1}$ bond (where $\mathrm{O}_{2}$ is the water oxygen) and the simultaneous migration of a hydrogen atom from $\mathrm{O}_{2}$ to $\mathrm{O}_{1}$, overcoming an energy barrier of $7.5 \mathrm{kcal} \mathrm{mol}^{-1}$ [see the corresponding transition-state TS(S1-S3) in Figure 5 

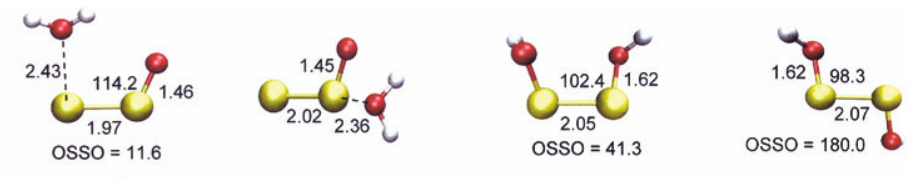

S1 (-17.9)

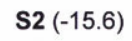

S3 (-28.5)

S4 (-28.8)
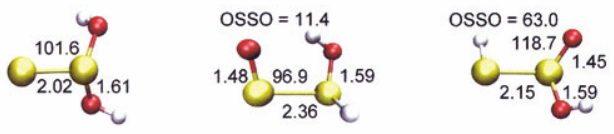

S5 (-22.7)

S6 (-18.0)

S7(-11.7)

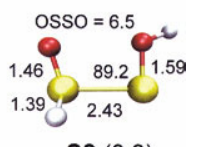

S8 (0.3)

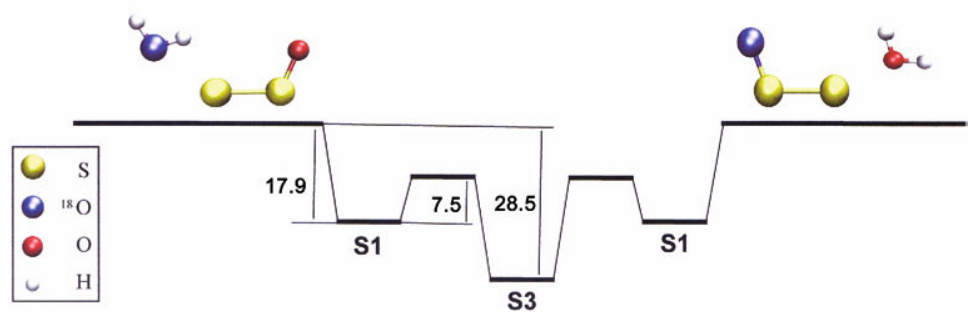

Figure 4. Schematic representation of doublet $\left[\mathrm{H}_{2}, \mathrm{~S}_{2}, \mathrm{O}_{2}\right]^{++}$species. Energy values $\left(\mathrm{kcal} \mathrm{mol}^{-1}\right)$ are relative to non interacting $\mathrm{S}_{2} \mathrm{O}^{+}$and $\mathrm{H}_{2} \mathrm{O}$. Bond lengths are in Ångstroms and angles in degrees. The potential energy surface relevant to the isotope exchange is depicted at the bottom of the figure.

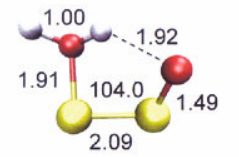

$$
\begin{aligned}
& \text { TS(S1-S3), }-10.4 \\
& \mathrm{E}_{\mathrm{a}}=7.5
\end{aligned}
$$
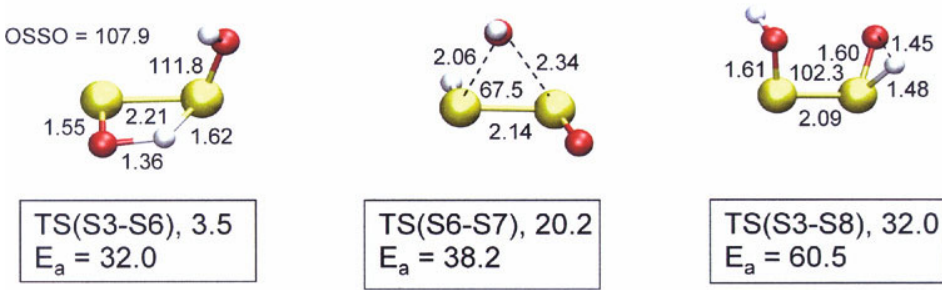

TS(S3-S8), 32.0 $\mathrm{E}_{\mathrm{a}}=60.5$

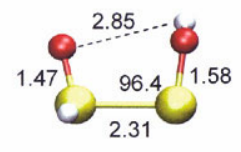

TS(S6-S8), 6.7 $\mathrm{E}_{\mathrm{a}}=24.7$

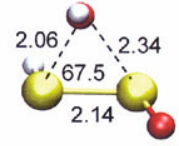

TS(S6-S7), 20.2 $E_{a}=38.2$

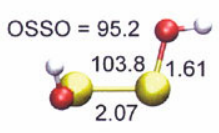

TS(S3-S4), -21.9 $E_{a}=6.6$

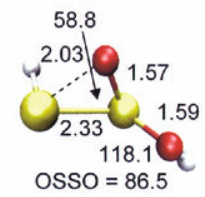

TS(S7-S8), 15.6 $E_{a}=27.3$

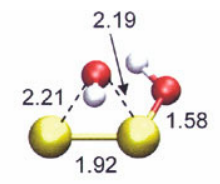

TS(S4-S5), 8.3 $E_{a}=37.1$

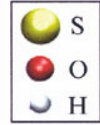

Figure 5. Schematic representation of transition states connecting different $\mathrm{H}_{2} \mathrm{~S}_{2} \mathrm{O}_{2}^{+}$species. Energy values $\left(\mathrm{kcal} \mathrm{mol}^{-1}\right.$ ) are relative to non interacting $\mathrm{S}_{2} \mathrm{O}^{+}$and $\mathrm{H}_{2} \mathrm{O}$. Bond lengths are in Angstroms and angles in degrees. 
and the energy diagram of Figure 4]. In TS(S1-S3) the new $\mathrm{O}_{2}-\mathrm{S}_{1}$-forming bond is $1.91 \AA$ and the distance between the migrating hydrogen and $\mathrm{O}_{1}$ is $1.92 \AA$. The two $\mathrm{OH}$ groups become anti oriented in $\mathbf{S 4}$, which is almost degenerate to $\mathbf{S} 3$, being only $0.3 \mathrm{kcal} \mathrm{mol}^{-1}$ more stable. This ion can be obtained from $\mathbf{S} 3$ by overcoming a barrier of $6.6 \mathrm{kcal} \mathrm{mol}^{-1}$ [TS(S3-S4)] and represents the lowest energy species located on the potential surface.

Other species characterized by different connectivity with respect to $\mathbf{S} 3$ and $\mathbf{S} 4$ are schematically represented in Figure 4: S5 $(\mathrm{HOS}(\mathrm{S}) \mathrm{OH}), \mathrm{S} 6$ (OSS$(\mathrm{H}) \mathrm{OH}), \mathbf{S 7}(\mathrm{HSS}(\mathrm{O}) \mathrm{OH})$, and $\mathbf{S 8}(\mathrm{HS}(\mathrm{O}) \mathrm{SOH})$ [21]. The S5 ion $\mathrm{HOS}(\mathrm{S}) \mathrm{OH}^{\cdot+}$ lies $4.8 \mathrm{kcal} \mathrm{mol}^{-1}$ lower in energy than S1, and can form from S4 (anti-HOS$\mathrm{SOH}^{++}$) by migration of an $\mathrm{OH}$ group from one sulfur atom to the adjacent one. However, because TS(S4-S5) lies $8.3 \mathrm{kcal} \mathrm{mol}^{-1}$ above $\mathrm{H}_{2} \mathrm{O}+\mathrm{S}_{2} \mathrm{O}^{+}$, the computed barrier is rather large (i.e., $37.1 \mathrm{kcal} \mathrm{mol}^{-1}$ ). The $\mathbf{S} 6$ ion $\mathrm{OSS}(\mathrm{H}) \mathrm{OH}^{\cdot+}$ is degenerate to the initially formed complex S1 (only $0.1 \mathrm{kcal} \mathrm{mol}^{-1}$ lower in energy) and can be obtained from the symmetrical S3 $\left(\mathrm{syn}-\mathrm{HOSSOH}^{+}\right)$or S4 $\left(\right.$ anti-HOSSOH $\left.{ }^{+}\right)$ions through migration of the hydrogen atom of one $\mathrm{SOH}$ moiety to the sulfur of the other $\mathrm{SOH}$ moiety [transition-state TS(S3-S6)]. The corresponding barrier is $32.0 \mathrm{kcal} \mathrm{mol}^{-1}$. The $\mathbf{S} 7$ ion $\mathrm{HSS}(\mathrm{O}) \mathrm{OH}^{++}$is located about $12 \mathrm{kcal} \mathrm{mol}^{-1}$ below the reactants and 6.2 $\mathrm{kcal} \mathrm{mol}^{-1}$ higher than the initial complex S1. A transition state connects $\mathbf{S 7}$ to $\mathbf{S 6}$ [TS(S6-S7)]. This process, which is basically a migration of the $\mathrm{OH}$ group from one sulfur atom to the other one, has a rather large activation barrier of $38.2 \mathrm{kcal} \mathrm{mol}^{-1}$, given that TS(S6S7) is $20.2 \mathrm{kcal} \mathrm{mol}^{-1}$ above the reactants. The S8 ion $\mathrm{HS}(\mathrm{O}) \mathrm{SOH}^{+}$is almost degenerate to the asymptotic limit (only $0.3 \mathrm{kcal} \mathrm{mol}^{-1}$ above it) and can be reached following three different pathways. One path originates from the symmetrical S3 ion $\left(\mathrm{HOSSOH}^{\cdot+}\right.$ ) and involves the migration of the hydrogen atom from the oxygen to the sulfur within the same $\mathrm{SOH}$ moiety. The corresponding transition-state TS(S3-S8), however, is very

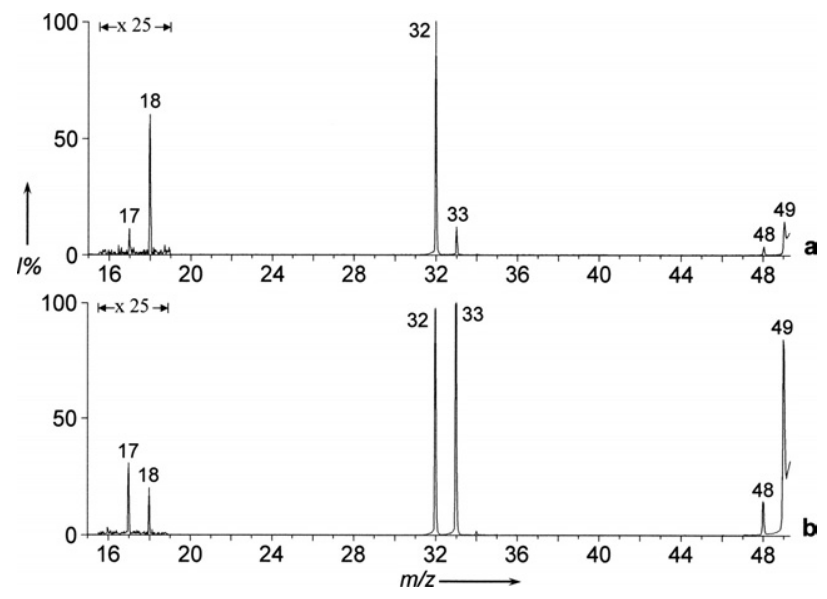

Figure 6. (a) High-resolution CAD/TOF spectrum of $\left[\mathrm{H}_{2}, \mathrm{~S}, \mathrm{O}\right]^{++}$ ions obtained by $\mathrm{S} / \mathrm{H}_{2} \mathrm{O}$ CI. (b) High-resolution CAD/TOF spectrum of $\left[\mathrm{H}_{2}, \mathrm{~S}, \mathrm{O}\right]^{++}$ions obtained by $\mathrm{S} / \mathrm{O}_{2} / \mathrm{H}_{2} \mathrm{O}$ CI. high in energy, lying about $32 \mathrm{kcal} \mathrm{mol}^{-1}$ above the reactants. Another path begins from S6 $\left[\mathrm{OSS}(\mathrm{H}) \mathrm{OH}^{{ }^{+}}\right.$] and involves the migration of a hydrogen atom from one sulfur atom to the adjacent one. The corresponding transition-state TS(S6-S8) has a barrier of $24.7 \mathrm{kcal}$ $\mathrm{mol}^{-1}$. The third path originates from S7 [HSS $(\mathrm{O}) \mathrm{OH}^{\cdot+}$ ] and is basically the migration of an oxygen atom from one sulfur atom to the other one. In this case also, the transition-state TS(S7-S8) is rather high in energy, being $15.6 \mathrm{kcal} \mathrm{mol}^{-1}$ above the asymptotic limit.

\section{The $\mathrm{S}_{2} \mathrm{O}^{\cdot+}$ Reactivity with Water}

The isotope exchange occurs by a simplified threewells potential energy surface, as depicted in Figure 4. CI experiments show that the scrambling is already complete in the source, where the most energetic and short-lived $\mathrm{H}_{2} \mathrm{~S}_{2}{ }^{18} \mathrm{OO}^{+}$fraction is sampled. The stable $\mathrm{H}_{2} \mathrm{~S}_{2}{ }^{18} \mathrm{OO}^{\cdot+}$ ionic fraction, sampled by CAD, is consistent with the symmetrical $\mathrm{HOSSOH}^{+}$intermediate S3 that has lost memory of the formation process. Such an intermediate nicely accounts for the fragmentation observed in the CAD spectrum that in fact is closely similar to that reported by Schmidt et al. [20], who generated the $\mathrm{HOSSOH}^{+}$ion by propene loss from ionized diisopropoxy disulfide $\mathrm{C}_{3} \mathrm{H}_{7^{-}}$ OSSO- $\mathrm{C}_{3} \mathrm{H}_{7}$.

The spectral features indicate that fragmentations diagnostic of other $\mathrm{H}_{2} \mathrm{~S}_{2} \mathrm{O}_{2}^{+}$species are assuredly minor reaction channels. As an example, the small CAD peak at $m / z 33$ hints at fragmentations occurring from species where the sulfur atom is the hydrogen-bearing site such as $\mathrm{OSS}(\mathrm{H}) \mathrm{OH}^{\cdot+}$ S6, $\mathrm{HSS}(\mathrm{O}) \mathrm{OH}^{++}$S7, and $\mathrm{HS}(\mathrm{O}) \mathrm{SOH}^{++}$ S8. The ion $\mathrm{HSS}(\mathrm{O}) \mathrm{OH}^{+}$S7 can fragment also by $\mathrm{SH}$ loss, and both the spectra of $\left[\mathrm{H}_{2} \mathrm{~S}_{2}{ }^{18} \mathrm{OO}\right]^{\cdot+}$ and $\left[\mathrm{H}_{2}{ }^{34} \mathrm{~S}_{2} \mathrm{O}_{2}\right]^{{ }^{+}}$(Figures 3b and $\mathrm{S} 1$ ) actually show a vanishingly small peak at $m / z$ 67, corresponding to $\mathrm{OS}^{18} \mathrm{OH}^{+}$and $\mathrm{O}^{34} \mathrm{SOH}^{+}$, respectively. Finally, the ion OSS $(\mathrm{H}) \mathrm{OH}^{\cdot+} \mathbf{S} 6$ is viable to fragmentation into $\mathrm{HOSH}^{++}$ by SO loss. In such case, the CAD spectra of both the $\left[\mathrm{H}_{2} \mathrm{~S}_{2}{ }^{18} \mathrm{OO}\right]^{\cdot+}$ and $\left[\mathrm{H}_{2}{ }^{34} \mathrm{~S}_{2} \mathrm{O}_{2}\right]^{\cdot+}$ ions show nonnegligible $\mathrm{m} / \mathrm{z} 52$ fragments corresponding to $\left[\mathrm{H}_{2}, \mathrm{~S},{ }^{18} \mathrm{O}\right]^{++}$and $\left[\mathrm{H}_{2},{ }^{34} \mathrm{~S}, \mathrm{O}\right]^{\cdot+}$ ions, respectively.

These findings raise the question of whether $\mathrm{S}_{2} \mathrm{O}^{++}$ displays any $\mathrm{S}^{\cdot+}$-transfer ability, in comparison to $\mathrm{O}_{3}^{+}$, which is a good $\mathrm{O}^{++}$donor [22]. Actually, under high-resolution conditions the source-generated $\mathrm{m} / \mathrm{z}$ 50 ion (Figure $2 \mathrm{~b}$ ) proves to be a mixture of two isobaric species: $\mathrm{S}^{18} \mathrm{O}^{++}$and $\left[\mathrm{H}_{2}, \mathrm{~S}, \mathrm{O}\right]^{\cdot+}$. The CAD spectrum of the latter is reported in Figure 6b. The $\mathrm{SOH}_{2}^{+}$ion and its more stable $\mathrm{HOSH}^{+}$isomer [23] have been distinguished by Iraqi and Schwarz by CAD mass spectrometry [24]. According to this structural analysis, we can safely conclude that a mixture of $\mathrm{SOH}_{2}^{+}$and $\mathrm{HOSH}^{+}$ions is generated in our conditions. The following experiment, however, demonstrates that $\mathrm{SOH}_{2}^{++}$is not generated by $\mathrm{S}^{\cdot+}$ transfer from $\mathrm{S}_{2} \mathrm{O}^{\cdot+}$ to $\mathrm{H}_{2} \mathrm{O}$. 
The $\left[\mathrm{H}_{2}, \mathrm{~S}, \mathrm{O}\right]^{++}$ion at $\mathrm{m} / \mathrm{z} 50$ was observed, even in the absence of $\mathrm{O}_{2}$, by chemical ionization of a gaseous mixture containing elemental sulfur and $\mathrm{H}_{2} \mathrm{O}$. It was separated from the isobaric $\mathrm{S}^{18} \mathrm{O}^{++}$and ${ }^{34} \mathrm{SO}^{-{ }^{+}}$ions, and its CAD spectrum was recorded (Figure 6a). The spectrum shows the $\mathrm{H}_{2} \mathrm{O}^{++}$peak and the $\mathrm{S}^{+} / \mathrm{HS}^{+}$ratio $(\sim 5)$ distinctive of the $\mathrm{SOH}_{2}^{+}$ion, likely formed by reaction of either $\mathrm{S}^{+}$or $\mathrm{S}_{2}^{+}$with water. After addition of $\mathrm{O}_{2}$ and maximization of the $\mathrm{S}_{2} \mathrm{O}^{++}$reactant ion, the spectrum changes clearly displaying formation of the $\mathrm{HOSH}^{++}$ ion $\left(\mathrm{OH}^{+}>\mathrm{H}_{2} \mathrm{O}^{++}, \mathrm{S}^{+} \approx \mathrm{HS}^{+}\right)$(Figure 6b). Thus we attribute the $\mathrm{SOH}_{2}^{+}$component to the reaction that does not involve $\mathrm{S}_{2} \mathrm{O}^{-+}$, and the $\mathrm{HOSH}^{++}$component to the reaction between $\mathrm{S}_{2} \mathrm{O}^{+}$and $\mathrm{H}_{2} \mathrm{O}$. The low yield indicates that $\mathrm{HOSH}^{++}$is formed by a fraction of slightly excited $\mathrm{S}_{2} \mathrm{O}^{++}$reactants through intermediates, such as the $\mathrm{OSS}(\mathrm{H}) \mathrm{OH}^{++}$ion $\mathbf{S 6}$, able to give $\mathrm{HOSH}^{++}$by $\mathrm{SO}$ loss. By contrast the intermediate $\left[\mathrm{OSS}-\mathrm{OH}_{2}\right]^{++} \mathrm{S} 1$ does not undergo $\mathrm{S}^{++}$transfer to the water molecule.

The result is consistent with the thermochemistry of the $\mathrm{S}^{++}$-transfer $\left(\mathrm{S}_{2} \mathrm{O}^{++}+\mathrm{H}_{2} \mathrm{O} \rightarrow \mathrm{SO}+\mathrm{SOH}_{2}^{+}\right)$that, based on available experimental and computational thermochemical data, can be evaluated to be endoergonic by about $35 \mathrm{kcal} \mathrm{mol}^{-1}$ [23, 25-27]. Compared to $\mathrm{O}_{3}^{+}$, the $\mathrm{S}_{2} \mathrm{O}^{++}$ion-not unexpectedly-displays a different reactivity with water. $\mathrm{O}_{3}^{+}$behaves as a $\mathrm{O}^{-+}$-donor producing the oxywater cation $\mathrm{OOH}_{2}^{+}$, the distonic isomer of the conventional more stable radical cation $\mathrm{HOOH}^{++}[28,29]$. Such a reactivity rests on the low dissociation energy of $\left.\mathrm{O}_{3}^{++} \mathrm{X}^{2} \mathrm{~A}_{1}\right)$ into $\mathrm{O}^{-+}$ and $\mathrm{O}_{2}(0.6 \mathrm{eV})[30]$ and the high $\mathrm{O}^{++}$affinity of water (evaluated $\sim 81 \mathrm{kcal} \mathrm{mol}^{-1}$ ) [25, 28]. Likewise these data account for the failure to observe any adduct between $\mathrm{O}_{3}^{+}$and water even at the highest investigated pressures [29]. In contrast, the dissociation energy of $\mathrm{S}_{2} \mathrm{O}^{++}$into $\mathrm{S}^{++}$and $\mathrm{SO}$ amounts to $75.5 \mathrm{kcal}$ mol $^{-1}[25,26]$, much higher than the $\mathrm{S}^{++}$affinity of water evaluated about $40 \mathrm{kcal} \mathrm{mol}^{-1}$ [23, 25-27]. In summary, the $\mathrm{S}_{2} \mathrm{O}^{-+}$ion behaves neither as $\mathrm{S}^{++}$- nor as $\mathrm{O}^{++}$-donor and yields stable adducts with water. These results confirm the ability of the $\mathrm{S}_{2} \mathrm{O}^{++}$cation to solvate nucleophiles, as for example SCO that transfers its sulfur atom to $\mathrm{S}_{2} \mathrm{O}^{++}$due to the presence of a good leaving group [4,5].

\section{Conclusions}

$\mathrm{S}_{2} \mathrm{O}^{++}$undergoes an intracomplex O-exchange reaction with water, with a rate constant $k=9.3 \times 10^{-11}$ $\pm 30 \% \mathrm{~cm}^{3} \mathrm{~s}^{-1}$ molecule $^{-1}$ at $298 \mathrm{~K}$. The reaction occurs by the symmetrical intermediate $\mathrm{HOSSOH}^{++}$ that can be stabilized under high-pressure conditions. The structural analysis shows no predominance of the initially formed $\left[\mathrm{S}_{2} \mathrm{O}-\mathrm{H}_{2}{ }^{18} \mathrm{O}\right]^{-+}$complex, pointing to the reaction as a route to bound $\mathrm{HOSSOH}^{+}$ ions.

\section{Acknowledgments}

This work has been financially supported by the Italian Government (PRIN-FIRB) and Rome University "La Sapienza." The authors thank Stefania Recaldin for editorial assistance.

\section{References}

1. Steudel, R. Sulfur-Rich Oxides $\mathrm{S}_{\mathrm{n}} \mathrm{O}$ and $\mathrm{S}_{\mathrm{n}} \mathrm{O}_{2}(\mathrm{n}>1)$. Top. Curr. Chem. 2003, 231, 203-230.

2. Schenk, W. A. Sulfur Oxides as Ligands in Coordination Compounds. Angew. Chem. Int. Ed. Engl. 1987, 26, 98-109.

3. Pandey, K. K. Electronic Structure and Coordinate Bonding Nature of Manganese (I) Disulfur Monoxide Complex $\left[\mathrm{MnS}_{2} \mathrm{O}^{+}\right.$. J. Mol. Struct. 1999, 491, 231-235

4. Cacace, F.; de Petris, G.; Rosi, M.; Troiani, A. Ionization of Atmospheric Gases Containing Ozone and Carbonyl Sulfide. Formation and Reactivity of $\mathrm{SO}^{+}$Ions. J. Phys. Chem. A 2001, 105, 1144-1149.

5. de Petris, G.; Rosi, M.; Troiani, A. $\mathrm{S}_{3} \mathrm{O}$ and $\mathrm{S}_{3} \mathrm{O}^{+}$in the Gas Phase: Ring and Open-chain Structures. Chem. Commun. 2006, 4416-4418.

6. Hapke, B. The Surface of Io: A New Model. Icarus 1989, 79, 56-74.

7. Johnson, R. E.; Nelson, M. L.; McCord, T. B.; Gradie, J. C. Analysis of Voyager Images of Europa: Plasma Bombardment. Icarus 1998, 75, 423-436.

8. Anderson, J. D.; Lau, E. L.; Sjogren, W. L.; Schubert, G.; Moore, V. B. Europa's Differentiated Internal Structure: Inferences from Two Galileo Encounters. Science 1997, 276, 1236-1239.

9. Johnson, R. E.; Killen, R. M.; Waite, J. H., Jr.; Lewis, W. S. Europa's Surface Composition and Sputter-Produced Ionosphere. Geophys. Res. Lett. 1998, 25, 3257-3260.

10. Smyth, W. H.; Marconi, M. L. Europa's Atmosphere, Gas Tori, and Magnetospheric Implications. Icarus 2006, 181, 510-526.

11. (a) Petrie, S.; Böhme, D. K. Ions in Space. Mass Spectrom. Rev. 2007, 26 , 258-280. (b) Smith, D.; Španel, P. Ions in the Terrestrial Atmosphere and in Interstellar Clouds. Mass Spectrom. Rev. 1995, 14, 255-278. (c) Smith, D. The Ion Chemistry of Interstellar Clouds. Chem. Rev. 1992, 92, 1473-1485.

12. Anicich, V. G. Evaluated Bimolecular Ion-Molecule Gas Phase Kinetics of Positive Ions for Use in Modeling Planetary Atmospheres, Cometary Comae, and Interstellar Clouds. J. Phys. Chem. Ref. Data 1993, 22, 1469-1569.

13. Bartmess, J. E.; Georgiadis, R. M. Empirical Methods for Determination of Ionization Gauge Relative Sensitivities for Different Gases. Vacuum 1983, 33, 149-153.

14. Olney, T. N.; Cann, N. M.; Cooper, G.; Brion, C. E. Absolute Scale Determination for Photoabsorption Spectra and the Calculation of Molecular Properties Using Dipole Sum-Rules. Chem. Phys. 1997, 233, 59-98.

15. Bowers, M. T.; Su, T. Interactions between Ions and Molecules; Plenum Press, New York, 1975. (b) Su, T.; Chesnavich, J. Parametrization of the Ion-Polar Molecule Collision Rate Constant by Trajectory Calculations. J. Chem. Phys. 1982, 76, 5183-5185.

16. Bernardi, F.; Cacace, F.; de Petris, G.; Pepi, F.; Rossi, I.; Troiani, A. Gas-Phase Reactions of Nitronium Ions with Acetylene and Ethylene: An Experimental and Theoretical Study. Chem. Eur. J. 2000, 6, 537-544.

17. Frisch, M. J., Trucks, G. W., Schlegel, H. B., Scuseria, G. E., Robb, M. A., Cheeseman, J. R., Montgomery, J. A. Jr., Vreven, T., Kudin, K. N., Burant, J. C., Millam, J. M., Iyengar, S. S., Tomasi, J., Barone, V., Mennucci, B., Cossi, M., Scalmani, G., Rega, N., Petersson, G. A., Nakatsuji, H., Hada,, M. Ehara, M., Toyota, K., Fukuda, R., Hasegawa, J., Ishida, M., Nakajima, T., Honda, Y., Kitao, O., Nakai, H., Klene, M., Li, X., Knox, J. E., Hratchian, H. P., Cross, J. B., Bakken, V., Adamo, C., Jaramillo, J., Gomperts, R., Stratmann, R. E., Yazyev, O., Austin, A. J., Cammi, R., Pomelli, C., Ochterski, J. W., Ayala, P. Y. Morokuma, K., Voth, G. A., Salvador, P., Dannenberg, J. J., Zakrzewski, V. G., Dapprich, S., Daniels, A. D., Strain, M. C., Farkas, O., Malick, D. K., Rabuck, A. D., Raghavachari, K., Foresman, J. B., Ortiz, J. V., Cui, Q., Baboul, A. G., Clifford, S., Cioslowski, J., Stefanov, B. B., Liu, G., Liashenko, A., Piskorz, P., Komaromi, I., Martin, R. L., Fox, D. J., Keith, T., Al-Laham, M. A., Peng, C. Y., Nanayakkara, A., Challacombe, M., Gill, P. M. W., Johnson, B., Chen, W., Wong, M. W., Gonzalez, C., Pople, J. A. Gaussian 03, Revision C. 02, Gaussian, Inc., Wallingford, CT, 2004.

18. Becke, A. D. Density-Functional Thermochemistry. III. The Role of Exact Exchange. J. Chem. Phys. 1993, 98, 5648-5652.

19. (a) Dunning, T. H. Gaussian Basis Sets for Use in Correlated Molecular Calculations. I. The Atoms Boron through Neon and Hydrogen. J. Chem. Phys. 1989, 90, 1007-1023. (b) Kendall, R. A.; Dunning, T. H.; Harrison, R. J. Electron Affinities of the First-Row Atoms Revisited. Systematic Basis Sets and Wave Functions. J. Chem. Phys. 1992, 96, 6796-6806. (c) Woon, D. E.; Dunning, T. H. Gaussian Basis Sets for Use in Correlated Molecular Calculations. III. The Atoms Aluminium through Argon. J. Chem. Phys. 1993, 98, 1358-1371.

20. Schmidt, H.; Steudel, R.; Sülzle, D.; Schwarz, H. Generation and Characterization of Dihydroxy Disulfide, HOSSOH: the Chainlike Isomer of Thiosulfurous Acid. Inorg. Chem. 1992, 31, 941-944.

21. A complete investigation of the potential surface has demonstrated the existence of additional minima with different connectivity (often involving cyclic structures) that are very high in energy and are not considered in this work. 
22. de Petris, G. Atmospherically Relevant Ion Chemistry of Ozone and Its Cation. Mass Spectrom. Rev. 2003, 22, 251-271 and references therein.

23. The $\mathrm{HSOH}^{+}$ion was computed to be more stable than $\mathrm{SOH}_{2}^{+}$by 17.5 kcal mol${ }^{-1}$. Decker, B. K.; Adams, N. G.; Babcock, L. M.; Crawford, T. D.; Schaefer, H. F., III. Thermokinetic Proton Transfer and Ab Initio Studies of the $\left[2 \mathrm{H}, \mathrm{S}, \mathrm{O}^{+}\right.$System. The Proton Affinity of HSO. J. Phys. Chem. A 2000, 104, 4636-4647.

24. Iraqi, M.; Schwarz, H. Experimental Evidence for the Gas Phase Existence of $\mathrm{HSOH}$ (hydrogen thioperoxide) and $\mathrm{SOH}_{2}$ (thiooxonium ylide). Chem. Phys. Lett. 1994, 221, 359-362.

25. Linstrom, P. J., Mallard,, W. G. NIST Chemistry WebBook, NIST Standard Reference Database Number 69, National Institute of Standards and Technology: Gaithersburg, MD, 2005.
26. Lodders, K. Revised and Updated Thermochemical Properties of the Gases Mercapto (HS), Disulfur Monoxide $\left(\mathrm{S}_{2} \mathrm{O}\right)$, Thiazyl (NS), and Thioxophosphino (PS). J. Phys. Chem. Ref. Data 2004, 33, 357-367.

27. Denis, P. A. The Enthalpy of Formation of the HSO Radical Revisited. Chem. Phys. Lett. 2005, 402, 289-293.

28. Schröder, D.; Schalley, C. A.; Goldberg, N.; Hrŭsák, J.; Schwarz, H. Gas-Phase Experiments Aimed at Probing the Existence of the Elusive Water Oxide Molecule. Chem. Eur. J. 1996, 2, 1235-1242.

29. de Petris, G.; Cartoni, A.; Cipollini, R.; Troiani, A. A Novel Route to $\mathrm{H}_{2} \mathrm{O}_{2}^{+}$ Ions via Direct Generation of the Oxywater Cation $\mathrm{H}_{2} \mathrm{OO}^{+}$. Int. J. Mass Spectrom. 2006, 249-250, 311-316.

30. Moseley, J. T.; Ozenne, J.-B.; Cosby, P. C. Photofragment Spectroscopy of $\mathrm{O}_{3}{ }^{+}$. J. Chem. Phys. 1981, 74, 337-341. 